\title{
High prevalence of undiagnosed COPD in a cohort of HIV-infected smokers
}

To the Editor:

Studies in HIV-infected populations in developed countries have shown an increased prevalence of chronic obstructive pulmonary disease (COPD) in comparison with their HIV-uninfected counterparts [1, 2]. This is due in part to higher prevalence of smoking in these populations. Studies have included subjects with or without a history of smoking [3, 4], specific populations (e.g. history of intravenous drug use (IDU) [5]), and African-American or Hispanic minorities in the USA [4, 5]. Few studies have been performed in Europe [3]. When looking at HIV-related factors, history of Pneumocystis infection or colonisation [6], HIV viral load $>200000$ copies. $\mathrm{mL}^{-1}$ [5] and antiretroviral therapy (ART) [4] were associated with COPD. However, further studies are needed.

The objective of our study was to evaluate the burden of COPD and associated factors in a French multicentric cohort of smoking, HIV-infected subjects aged $\geqslant 40$ years.

This was a cross-sectional prevalence study of COPD nested in the ANRS EP48 HIV-CHEST cohort, a French, multicentric, prospective study evaluating the relevance of low-dose chest tomography for early lung cancer diagnosis in HIV-infected subjects from 14 clinical centres (registered at www.clinicaltrials.gov with identifier NCT01207986). Inclusion criteria were age $\geqslant 40$ years, smoking history of $\geqslant 20$ pack-years within the last 3 years, a nadir $\mathrm{CD}^{+} \mathrm{T}$-cell count $<350 \mu \mathrm{L}^{-1}$ and last $\mathrm{CD} 4^{+} \mathrm{T}$-cell count $>100 \mu \mathrm{L}^{-1}$. Exclusion criteria were active cancer, an AIDS-defining disease, a lung infection in the previous 2 months, pregnancy, breastfeeding or contraindication to thoracic surgery. All subjects gave their informed consent. The study was approved by the institutional review board (Comité de Protection des Personnes Sud Méditerranée IV, Montpellier, France).

Lung function was evaluated by spirometry, plethysmography and diffusing capacity of the lung for carbon monoxide (DLCO). Laboratories followed the American Thoracic Society (ATS) and the European Respiratory Society (ERS) recommendations $[7,8]$. The primary outcome was the prevalence of COPD as defined by the Global Initiative for Chronic Obstructive Lung Disease (GOLD) recommendations: forced expiratory volume in $1 \mathrm{~s}(\mathrm{FEV} 1) /$ forced vital capacity $(\mathrm{FVC})$ ratio $<0.70$ after administration of salbutamol [9]. Subjects were classified as GOLD 1 (mild), GOLD 2 (moderate), GOLD 3 (severe) or GOLD 4 (very severe) if their measured $\mathrm{FEV} 1$ was $\geqslant 80 \%, \geqslant 50 \%$ to $<80 \%, \geqslant 30 \%$ to $<50 \%$ or $<30 \%$ of that predicted using the ERS standardisation of lung function test equations [10] for the nonsmoking Caucasian population, respectively. Percentage of normal total lung capacity (TLC), residual volume (RV) and RV/TLC ratio were calculated according to the ERS standardisation of lung function test equations [8] and DLCO using the ATS criteria [7].

A generalised linear mixed model with centre as a random effect was used to evaluate the association between COPD and age (years), sex, low body mass index (BMI) $\left(<18.5 \mathrm{~kg} \cdot \mathrm{m}^{-2}\right.$ ), smoking history (per 5-pack-year increase), cannabis inhalation (yes versus no), hepatitis $\mathrm{C}$ virus (HCV) infection, history of Pneumocystis pneumonia, last viral load $<50$ copies $\mathrm{mL}^{-1}$, last level of $\mathrm{CD} 4^{+} \mathrm{T}$-cells (per $100-\mu \mathrm{L}^{-1}$ increase), nadir level of $\mathrm{CD}^{+}$T-cells $<200 \mu \mathrm{L}^{-1}$ and duration of ART. Data on ethnic origin were unavailable. To account for COPD overdiagnosis [11], we performed a sensitivity analysis with GOLD $\geqslant 2$ as the outcome and calculated COPD prevalence according to the FEV1/FVC below the lower limit of normal (LLN) definition [10].

Between March 2011 and June 2012, spirometry, plethysmography and DLCO measurements were performed in 338, 301 and 199 of the 442 subjects from the ANRS EP48 study, respectively (table 1). COPD was present in 88 (26\%) subjects: 31 (35\%), 50 (57\%) and seven (8\%) had mild, moderate and severe COPD, respectively. In $64(\sim 74 \%)$ subjects, COPD was previously unknown. Using the FEV1/ FVC $<$ LLN definition, COPD prevalence was 22\% (75 subjects): 23 (31\%) of whom had mild, 45 (60\%) had moderate and seven (9\%) severe COPD.

In univariate analyses, factors associated with COPD with a p-value $<0.20$ were age (OR 2.1, 95\% CI $1.4-$ 3.2; $\mathrm{p}<0.001$ ), low BMI (OR 2.4, 95\% CI 1.1-5.0; $\mathrm{p}=0.02$ ), $\mathrm{CD}^{+}$cell count (OR 0.9, 95\% CI 0.8-1.0; 
TABLE 1 Clinical, spirometric and plethysmographic characteristics

\begin{tabular}{|c|c|c|c|}
\hline Characteristics & Total population & COPD & Absence of COPD \\
\hline Subjects & $338(100)$ & $88(26)$ & $250(74)$ \\
\hline Age years & $50(46-53)$ & $52(48-56)$ & $49(46-53)$ \\
\hline Females & $58(17)$ & $13(15)$ & $45(18)$ \\
\hline Low BMI" & $36(11)$ & $15(17)$ & $21(8)$ \\
\hline Smoking duration years & $30(27-35)$ & $34(29-39)$ & $30(27-34)$ \\
\hline Smoking pack-years & $30(25-38)$ & $34(27-40)$ & $30(25-37)$ \\
\hline History of cannabis consumption & $117(35)$ & $36(41)$ & $81(32)$ \\
\hline History of IDU & $88(26)$ & $32(36)$ & $56(22)$ \\
\hline $\mathrm{CD4}^{+}$cell count $\mu \mathrm{L}^{-1}$ & $571(395-763)$ & $498(345-707)$ & $594(427-780)$ \\
\hline Nadir $\mathrm{CDL}^{+}$cell count $\mu \mathrm{L}^{-1}$ & $177(76-260)$ & $158(71-232)$ & $182(83-267)$ \\
\hline Nadir $\mathrm{CDL}^{+}$cell count $<200 \mu \mathrm{L}^{-1}$ & $195(58)$ & $54(61)$ & $141(56)$ \\
\hline History of AIDS-defining complication & $97(29)$ & $31(35)$ & $66(26)$ \\
\hline Known duration of HIV infection years & $17(10-22)$ & $19(11-24)$ & $17(10-21)$ \\
\hline Duration of HIV treatment years & $14(7-16)$ & $13(7-16)$ & $14(7-16)$ \\
\hline Last viral load $<50$ copies $\cdot \mathrm{mL}^{-1}$ & $298(88)$ & $78(89)$ & $220(88)$ \\
\hline HCV infection & $100(30)$ & $35(40)$ & $65(26)$ \\
\hline History ofPneumocystis pneumonia & $28(8)$ & $11(13)$ & $17(7)$ \\
\hline FEV 1 L & $3.2(2.6-3.7)$ & $2.5(2.0-2.9)$ & $3.4(2.9-3.8)$ \\
\hline FEV $1 \%$ predicted & $89(76-98)$ & $71(59-79)$ & $93(86-101)$ \\
\hline $\mathrm{FEV}_{1} / \mathrm{FVC}$ & $0.74(0.68-0.80)$ & $0.61(0.54-0.66)$ & $0.77(0.74-0.81)$ \\
\hline TLC ${ }^{\pi} \mathrm{L}$ & $7.1(6.2-7.9)$ & $7.5(6.7-8.4)$ & $6.9(6.1-7.7)$ \\
\hline TLC $\%$ predicted & $107(97-116)$ & $114(104-126)$ & $104(96-112)$ \\
\hline $\mathbf{R V}^{\S} \mathrm{L}$ & $2.5(2.1-3.0)$ & $3.1(2.3-3.9)$ & $2.4(2.0-2.8)$ \\
\hline $\mathbf{R V}^{\S} \%$ predicted & $119(100-147)$ & $152(108-175)$ & $114(99-133)$ \\
\hline $\mathrm{RV} / \mathrm{TLC}^{\S}$ & $37(32-42)$ & $41(36-49)$ & $35(31-40)$ \\
\hline RV/TLC $\$$ \% predicted & $108(93-121)$ & $120(101-139)$ & $104(92-117)$ \\
\hline$D\left\llcorner c 0^{f, \# \#} \%\right.$ predicted & $68(59-83)$ & $62(52-76)$ & $71(62-86)$ \\
\hline
\end{tabular}

Data are presented as $\mathrm{n}(\%)$ or median (interquartile range). COPD: chronic obstructive pulmonary disease; BMI: body mass index; IDU: intravenous drug use; HCV: hepatitis C virus; FEV1: forced expiratory volume in $1 \mathrm{~s}$; FVC: forced vital capacity; TLC: total lung capacity; RV: residual volume; DLco: diffusing capacity of the lung for carbon monoxide. ${ }^{\#}:<18.5 \mathrm{~kg} \cdot \mathrm{m}^{-2} ;{ }^{\uparrow}: \mathrm{n}=305 ;{ }^{\S}: \mathrm{n}=302 ;{ }^{f}$ : corrected for haemoglobin; ${ }^{\# \#}: \mathrm{n}=199$.

$\mathrm{p}=0.03$ ), HCV infection (OR 1.8, 95\% CI 1.1-3.1; p=0.02), history of Pneumocystis pneumonia (OR 2.0, 95\% CI 0.9-4.5; $\mathrm{p}=0.11$ ) and smoking (OR 1.1, 95\% CI 1.0-1.2; $\mathrm{p}=0.10)$. In multivariate analysis, age (OR 2.3, 95\% CI 1.4-3.6; $\mathrm{p}<0.001$ ), low BMI (OR 2.2, 95\% CI 1.0-4.9; $\mathrm{p}=0.04$ ) and HCV infection (OR 1.9, 95\% CI 1.1-3.4; $\mathrm{p}=0.02$ ) were independently associated with COPD at a 5\% threshold, but $\mathrm{CD} 4^{+}$cells (OR 0.9, 95\% CI 0.8-1.0; $\mathrm{p}=0.08$ ), history of Pneumocystis pneumonia (OR 2.1, 95\% CI 0.9-5.0; $\mathrm{p}=0.10$ ) and smoking (OR 1.0, 95\% CI 0.9-1.2; p=0.55) were not.

In the sensitivity analysis, factors associated with GOLD $\geqslant 2$ were age (OR 2.0, 95\% CI 1.2-3.2; $\mathrm{p}<0.01$ ) and low BMI (OR 3.1, 95\% CI 1.4-6.8; $\mathrm{p}<0.01$ ). CD4 $4^{+}$cell count (OR 0.9, 95\% CI 0.8-1.0; p=0.05), history of Pneumocystis pneumonia (OR 2.2, 95\% CI 0.9-5.5; p=0.09) and intensity of smoking (OR 1.0, 95\% CI $0.9-1.2 ; \mathrm{p}=0.54)$ were not.

The rate of COPD in our selected HIV-infected population is in the range of that reported in the general population, such as in Salzburg, Austria, in the Burden of Obstructive Lung Disease study [12]. Prevalence of COPD in our selected population was still high using the $\mathrm{FEV}_{1} / \mathrm{FVC}<\mathrm{LLN}$ definition for COPD diagnosis. COPD was also underdiagnosed, as described in the general population [13], due to insufficient COPD early diagnosis/screening of high-risk subjects.

Age and low BMI were associated with COPD, as previously described [11]. Smoking was not significantly associated with COPD in the multivariate analysis. This might be due to the limited range of accumulated doses and confounding by age. The role of cannabis in obstructive lung disease is conflicting in the literature [14] and we could not conclude on its relevance to COPD prevalence in our cohort as we lacked precise quantitative estimation of cannabis consumption. HCV infection was associated with COPD only in the primary analysis. This result may be due to confounders, as most intravenous drug users are infected by $\mathrm{HCV}$, or to a true lack of association, as was reported in a recent study [15]. Concerning nadir 
$\mathrm{CD}^{+}$cell count, duration of ART and viral load, conclusions should be drawn cautiously, as all subjects had a nadir count $<350 \mu \mathrm{L}^{-1}$ and nearly all had an undetectable viral load due to high ART coverage. Finally, last $\mathrm{CD}^{+}$cell count and Pneumocystis pneumonia history were not associated with COPD, which could be explained by lack of statistical power.

We found an increase in RV, TLV and the RV/TLC ratio in most subjects with COPD, consistent with emphysema or gas trapping. Values of the corrected DLCO were low, underscoring impairment of the blood-air barrier in COPD and non-COPD subjects. DLCO reduction in the HIV-infected has been associated with smoking, but also with low $\mathrm{CD}^{+}$cell counts $[16,17]$, possibly through enhanced local inflammation and subacute infections.

Our study has limitations. The cross-sectional design can only reveal associations between factors and COPD. In addition, symptoms and quality of life assessed using validated questionnaires were not recorded. Finally, we did not correct FEV1 and FVC values for ethnic origin [10]. However, these corrective factors would have only modified the numbers of subjects in the different GOLD stages, as FEV1/FVC remains the same, and have not been validated in sub-Saharan Africans, the major ethnic minority in the French HIV-infected population [10].

In conclusion, prevalence of COPD in our selected population was high and COPD was mostly undiagnosed. Our study advocates early, active diagnosis of COPD by spirometry in similar HIV-infected smokers, and smoking cessation in all HIV-infected subjects.

0 $@$ ERSpublications

COPD prevalence is $26 \%$ in an $\mathrm{HIV}$-infected cohort of smokers aged $\geqslant 40$ years and was largely underdiagnosed http://ow.ly/CkVzo

Alain Makinson ${ }^{1-3}$, Maurice Hayot ${ }^{4}$, Sabrina Eymard-Duvernay ${ }^{2}$, Mylène Quesnoy ${ }^{2}$, François Raffi ${ }^{5}$, Laurence Thirard ${ }^{6}$, Fabrice Bonnet ${ }^{7}$, Pierre Tattevin ${ }^{8}$, Sophie Abgrall ${ }^{9}$, Xavier Quantin ${ }^{10}$, Hervé Léna ${ }^{11}$, Sébastien Bommart ${ }^{12}$, Jacques Reynes ${ }^{1,2}$, Vincent Le Moing ${ }^{1,2}$ and the ANRS EP48 HIV CHEST Study Team ${ }^{13}$ ${ }^{1}$ Infectious and Tropical Diseases Dept, University Hospital Montpellier 1, Montpellier, France. ${ }^{2}$ UMI 233, IRD, University Montpellier 1, Montpellier, France. ${ }^{3}$ Dept of Internal Medicine, Clinique Beau-Soleil, Montpellier, France. ${ }^{4}$ INSERM U-1046, University Hospital Montpellier 1, Dept of Clinical Physiology, University of Montpellier I and II, Montpellier, France. ${ }^{5}$ ANRS, Paris, France. ${ }^{6}$ Pneumology Dept, Tourcoing University Hospital, Tourcoing, France. ${ }^{7}$ Internal Medicine and Infectious Diseases Dept, University Hospital Bordeaux, INSERM U897, Bordeaux, France. ${ }^{8}$ Infectious Diseases and Intensive Care Unit, Pontchaillou University Hospital, Rennes, France. ${ }^{9}$ Infectious and Tropical Diseases Dept, Groupement Hospitalier Nord, Bobigny, France. ${ }^{10}$ Thoracic Oncology Unit, University Hospital Montpellier, Montpellier, France. ${ }^{11}$ Respiratory Medicine Dept, Pontchaillou University Hospital, Rennes, France. ${ }^{12}$ Dept of Radiology and INSERM U 1046, University Hospital Montpellier, Montpellier, France. ${ }^{13}$ For a list of the ANRS EP48 HIV CHEST Study Team members and their affiliations, see the Acknowledgements section.

Correspondence: Alain Makinson, Infectious and Tropical Diseases Dept, University Hospital Montpellier 1, UMI 233, 80 Avenue Augustin Fliche, 34090, Montpellier, France. E-mail: a-makinson@chu-montpellier.fr

Received: July 152014 | Accepted after revision: Sept 202014 | First published online: Oct 162014

Support statement: This work was supported by the Agence Nationale de Recherche sur le SIDA et les Hépatites Virales.

Conflict of interest: Disclosures can be found alongside the online version of this article at erj.ersjournals.com

Acknowledgements: The members of the ANRS EP48 HIV CHEST Study Team are: Yazdan Yazdanpanah, Antoine Cheret, Faïza Ajana, Isabelle Alcaraz, Véronique Baclet, Hugues Melliez, Michel Valette, Nathalie Viget, Xavier de la Tribonniere, Thomas Huleux, Séverine Bonne, Raphaël Biekre, Armelle Pasquet, Christophe Allienne, Jean Marie Behra, Agnès Meybeck and Emmanuelle Aissi (Hôpital Gustave Dron, Tourcoing, France); Sophie Abgrall, Olivier Bouchaud, Régine Barruet, François Rouges, Tania Kandel, Fréderic Mechai, Pierre-Yves Brillet and Michel Brauner (Hôpital Avicenne, Bobigny, France); Pierre Dellamonica, Francine de Salvador, Eric Cua, Anne Leplatois, Alissa Naqvi, Jacques Durant, Carole Ceppi, Frédéric Sanderson, Eric Rosenthal, Madleen Chassang, Patrick Chevallier and Brigitte Dunais (Hôpital l'Archet, Nice, France); Pierre Tattevin, Hervé Lena, Pierre-Axel Lentz, Christian Michelet, Cédric Arvieux, Mathieu Revest, Faouzi Souala, Jean-Marc Chapplain, Hélène Leroy and Catherine Meunier (Hôpital Pontchailloux, Rennes, France); Isabelle Poizot-Martin, Olivia Faucher, Amélie Menard, Sylvie Bregigeon, Perrine Geneau de Lamarliere, Pierre Champsaur, Olivier Durieux and Nicolas Cloarec (Hôpital Ste Marguerite, Marseille, France); François Raffi, Clotilde Allavena, Nicolas Feuillebois, Olivier Mounoury, Sabelline Bouchez, Eric Billaud, Véronique Reliquet, Bénédicte Bonnet, Cécile Brunet, Patrick Point, David Boutoille, Pascale Morineau le Houssine and Anne Sophie Delemazure (Hôpital Hotel Dieu, Nantes, France); Claudine Duvivier, Emilie Catherinot, Michka Shoai Tehrani and Sylvain Poiree (Hôpital Necker, Paris, France); David Zucman, Catherine Majerholc, Louis-Jean Couderc, François Mellot and Antoine Sherrer (Hôpital Foch, Suresnes, France); Tristan Ferry, Joseph Koffi, André Boibieux, Patrick Miailhes, Laurent Cotte, Thomas Perpoint, Joanna Lippman, Claude Augustin Norman, Francois Biron, Agathe Senechar and Florence Ader (Hôpital La Croix Rousse, Lyon, France); Gilles Pialloux, Thomas l'Yavanc, Laurence Slama, Julie Chas, Sophie le Nagat, Antoine Khalil and Marie France Carette (Hôpital Tenon, Paris, France); Fabrice Bonnet, Philippe Morlat, Denis Lacoste, Marie VANDENHENDE, Marie Catherine Receveur, Francois Paccalin, Sabrina Caldato, Noëlle Bernard, Mojgan Hessemfar, Thierry Pistone, Denis Malvy, Pierre Thibaut, Marie Carmen Pertusa, Olivier Cornelou, Francois Laurent, Patrick Mercie, Isabelle Faure, Denis Dondia, Cedric Martell and Pierre Duffau 
(Hôpital St André, Bordeaux, France); Jean Marc Mauboussin, Claudine Barbuat, Isabelle Rouanet and Liliane Metge (Hôpital Carémeau, Nimes, France); and Jacques Reynes, Vincent le Moing, Jean-Marc Jacquet, Nadine Atoui, Mickael Loriette, David Morquin, Vincent Fauchere, Carine Favier, Corinne Merle, Vincent Baillat, Antoine da Silva, Rachid Mansouri, Christina Psomas, Sébastien Bommart, Hélène Kovacsik-Vernhet, Jean-Louis Pujol, Xavier Quantin and Maurice Hayot (Hôpital Gui de Chauliac, Montpellier, France).

This study was presented in part at the 21st Conference on Retrovirus and Opportunistic Infections in Boston, MA, USA, between March 3 and 6, 2014.:

We thank the trial participants, and the coordinators, engineers and technicians who made this study possible: Suzanne Izard, Jonathan Lalet, Amandine Cournil and Bruno Granouillac (UMI 233, IRD, University Montpellier 1, Montpellier, France).

\section{References}

1 Crothers K, Huang L, Goulet JL, et al. HIV infection and risk for incident pulmonary diseases in the combination antiretroviral therapy era. Am J Respir Crit Care Med 2010; 183: 388-395.

2 Madeddu G, Fois AG, Calia GM, et al. Chronic obstructive pulmonary disease: an emerging comorbidity in HIV-infected patients in the HAART era? Infection 2012; 41: 347-353.

3 Samperiz G, Guerrero D, Lopez M, et al. Prevalence of and risk factors for pulmonary abnormalities in HIV-infected patients treated with antiretroviral therapy. HIV Med 2014; 15: 321-329.

4 George MP, Kannass M, Huang L, et al. Respiratory symptoms and airway obstruction in HIV-infected subjects in the HAART era. PLoS One 2009; 4: e6328

5 Drummond MB, Kirk GD, Astemborski J, et al. Association between obstructive lung disease and markers of HIV infection in a high-risk cohort. Thorax 2012; 67: 309-314.

6 Morris A, Alexander T, Radhi S, et al. Airway obstruction is increased in pneumocystis-colonized human immunodeficiency virus-infected outpatients. J Clin Microbiol 2009; 47: 3773-3776.

7 Macintyre N, Crapo RO, Viegi G, et al. Standardisation of the single-breath determination of carbon monoxide uptake in the lung. Eur Respir J 2005; 26: 720-735.

8 Standardized lung function testing. Official statement of the European Respiratory Society. Eur Respir J 1993; 6 Suppl. 16:1-100

9 Global Initiative for Chronic Obstructive Lung Disease. Global Strategy for the Diagnosis, Management, and Prevention of Chronic Obstructive Pulmonary Disease. www.goldcopd.org/uploads/users/files/GOLD_Report_2014_ Jun11.pdf Date last updated: June 11, 2014.

10 Quanjer PH, Stanojevic S, Cole TJ, et al. Multi-ethnic reference values for spirometry for the 3-95-yr age range: the global lung function 2012 equations. Eur Respir J 2012; 40: 1324-1343.

11 Quanjer PH, Enright PL, Miller MR, et al. The need to change the method for defining mild airway obstruction. Eur Respir J 2011; 37: 720-722.

12 Buist AS, Vollmer WM, McBurnie MA. Worldwide burden of COPD in high- and low-income countries. Part I. The burden of obstructive lung disease (BOLD) initiative. Int J Tuberc Lung Dis 2008; 12: 703-708.

13 Hill K, Goldstein RS, Guyatt GH, et al. Prevalence and underdiagnosis of chronic obstructive pulmonary disease among patients at risk in primary care. CMAJ 2010; 182: 673-678.

14 Tashkin DP. Effects of marijuana smoking on the lung. Ann Am Thorac Soc 2013; 10: 239-247.

15 Fischer WA II, Drummond MB, Merlo CA, et al. Hepatitis C virus infection is not an independent risk factor for obstructive lung disease. COPD 2014; 11: 10-16.

16 Crothers K, McGinnis K, Kleerup E, et al. HIV infection is associated with reduced pulmonary diffusing capacity. J Acquir Immune Defic Syndr 2013; 64: 271-278.

17 Gingo MR, He J, Wittman C, et al. Contributors to diffusion impairment in HIV-infected persons. Eur Respir J 2013; 43: 195-203.

\section{Cladribine improves lung cysts and pulmonary function in a child with histiocytosis}

To the Editor:

Langerhans' cell histiocytosis $(\mathrm{LCH})$ is a rare disease of unknown aetiology involving accumulation of Langerhans' cells organised in granuloma, in various organs [1]. Pulmonary LCH (PLCH) is characterised by focal Langerhans' cell granulomas infiltrating and destroying distal bronchioles, which results in cysts, major destruction of the pulmonary tissue and pneumothorax [2,3]. PLCH is rare in children $<18$ years old.

When cysts are present, in children or adults, the disease is usually considered no longer active, and no treatment is effective for chronic cysts. The long-term outcome is marked by a slow progression to 